\title{
APOPTOSIS ACTIVATION IN PIG LEUKOCYTES AFTER PHAGOCYTOSIS OF Salmonella typhimurium
}

\author{
E. MATALOVÁ ${ }^{1}$, A. ŠPANOVÁ ${ }^{2}$, F. KOVÁR̆ ${ }^{1}{ }^{1}$, M. HEROLDOVÁ ${ }^{2}$ \\ ${ }^{1}$ Department of Physiology and Pathophysiology, Faculty of Veterinary Medicine, University of Veterinary \\ and Pharmaceutical Sciences, Brno, Czech Republic \\ ${ }^{2}$ Department of Microbiology, Faculty of Science, Masaryk University, Brno, Czech Republic \\ Received December 12, 1999 \\ Accepted February 10, 2000 \\ Abstract \\ Matalová E., A. Španová, F. Kovářů, M. Heroldová: Apoptosis Activation in Pig \\ Leukocytes after Phagocytosis of Salmonella typhimurium. Acta Vet. Brno 2000, 69: 11-15. \\ In this study we examined the effect of phagocytosis of living bacteria on apoptotic changes of \\ DNA in pig leukocytes. The aim of this work was to observe how phagocytosis and killing of \\ microorganisms can influence the survival of pig leukocytes. \\ Blood samples were cultivated with suspension of Salmonella typhimurium LB 5000 up to $48 \mathrm{~h}$ \\ at a temperature of $37^{\circ} \mathrm{C}$. In the experimental groups, killed bacteria and microspheric particles, \\ respectively, were used to determine the influence of the phagocytic process itself. In given \\ intervals, samples of cultivated cells were taken for DNA analysis. DNA ladder assay was used for \\ qualitative apoptotic DNA breaks detection by gel electrophoresis and TUNEL AP test for \\ quantification of apoptotic changes. Cell morphology was observed after May-Grünwald Giemsa- \\ staining under light microscope. \\ Spontaneous DNA degradation in the control group was observed after $8 \mathrm{~h}$. In contrast, cells \\ cultivated with microspheric particles or killed bacteria became apoptotic as soon as after $4 \mathrm{~h}$. \\ already. In the group exposed to living bacteria the apoptotic DNA degradation was slowed down \\ and detected after $48 \mathrm{~h}$ mainly, while the other groups showed features of necrosis. \\ These results suggest that the process of phagocytosis itself activates the apoptotic programme \\ in phagocytic cells of the pig immune system but the presence of phagocyted living bacteria can \\ delay this activation.
}

Apoptosis, phagocytosis, pig leukocytes, Salmonella typhimurium LB 5000

Apoptotis - a way of programmed cell death - is a physiological genetically controlled process.

Apoptosis (Kerr et al. 1972) is involved in embryogenesis, tissue renewal as well as in damaged and potencially dangerous cells liquidation. In contrast to pathological necrosis, apoptosis enables effective elimination of cells without inflammatory reaction due to keeping cytoplasmic membrane integrity. Apoptotic debris (bodies) are recognised by the phagocytic system of the organism and eliminated. Programmed cell death (PCD) can be activated by different extra- and intracellular factors. Knowledge of these PCD influencing factors and their mechanisms is extremely important for targeted modulation of PCD.

Participation in non-specific immune response of the organism is the major task of phagocyting blood cells. Polymorphonuclear granulocytes (PMN) are mainly responsible for elimination of pathogens (Sládek et Ryšánek 1999). This role involves phagocytosis and killing of microorganisms. For this purpose, the phagocyting cells possess a variety of receptors and enzymatic mechanisms enabling them to engulf and kill microbes (Morel et al. 1991; Lawrence 1992). After their mission, PMN undergo apoptotic process and are eliminated from blood circulation by the monocytes/macrophages system (Fesus et al. 1991; Allen et al. 1997; Meszaros et al. 1999).

\section{Address for correspondence:}

Eva Matalová

Institute of Physiology and Pathophysiology

Republic
Rcience
Phone: +420-5-41562234

Fax: +420-5-49211482

http://www.vfu.cz/acta-vet/actavet.htm 
In this work we tested the influence of phagocytosis of Salmonella typhimurium LB 5000 on survival and apoptotis activation in pig leukocytes in vitro.

Bacterial suspension

\section{Materials and Methods}

Laboratory strain of Salmonella typhimurium LB 5000 was grown overnight in LB medium (10 g Bacto trypton, $5 \mathrm{~g}$ Bacto yeast extract, $5 \mathrm{~g} \mathrm{NaCl}$ in $1000 \mathrm{ml} \mathrm{H} \mathrm{O}$ ) and then washed twice with PBS buffer (phosphate-buffer saline:

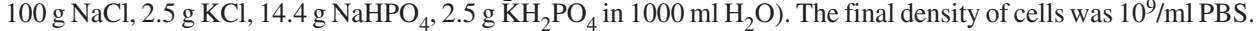
Suspension with killed bacteria was obtained after heating the culture $30 \mathrm{~min} / 72{ }^{\circ} \mathrm{C}$.

Samples

Blood samples $(25 \mathrm{ml}$ ) were taken from 12 healthy 4-month-old pigs on empty stomach (Duroc breed, 6 males, 6 females, Agriculture Farm, Nové Dvory) one hour prior to the experiment. Blood samples were stabilized with heparin $(12 \mathrm{i}$. u. $/ \mathrm{ml})$ and cultivated in vitro $\left(37^{\circ} \mathrm{C}\right)$ for $48 \mathrm{~h}$.

Microspheric particles

Microspheric particles (diameter 1,5 $\mu \mathrm{m}$ ) obtained from Artim, Czech Republic, were resuspended in adequate volume of PBS and used for phagocytic index and activity demonstration.

Phagocytosis of bacteria

Blood samples divided into four groups were incubated $\left(37^{\circ} \mathrm{C}\right)$ in Falcon tubes up to $48 \mathrm{~h}$. Simultaneously, phagocytic index and activity were tested using standard method (MSHP kit, RK 031, Artim, Praha, Czech Republic). The experiment was started with addition of bacterial cells and MSHP, respectively. In given intervals $(1,4,8,12,24,48 \mathrm{~h}$ after start of experiment), samples for DNA analysis were taken.

Group 1 - negative control, only adequate volume of PBS was added, group 2 - control of phagocytosis with microspheric particles in PBS, group 3 was cultivated with killed bacteria in PBS, and experimental group 4 with suspension of living bacteria S. typhimurium LB 5000 in PBS.

Bactericidal capacity of phagocytes

The ability of phagocytic leukocytes to kill living bacteria cells $S$. typhimurium LB 5000 was measured by the standard CFU (colony forming units) method. Briefly, phagocytic cells were incubated for 1,2 and $3 \mathrm{~h}$ with bacteria. Then the samples were washed from free bacteria (twice in PBS) and $900 \mu \mathrm{l}$ of ice-cold distilled water was added to the suspensions to lyse phagocytic cells. These lysates were diluted in LB medium and placed onto LB agar plates. Colonies were counted after incubation for $24 \mathrm{~h}$ at $37^{\circ} \mathrm{C}$ and the percentage of killed microorganisms was calculated.

DNA Ladder Assay

To determine apoptotic DNA fragments (Wyllie et al. 1980 Hale et al. 1996) blood samples were digested in lysis buffer $\left(50 \mathrm{mM}\right.$ Tris - $\mathrm{pH} 8,100 \mathrm{mM} \mathrm{NaCl}, 100 \mathrm{mM}$ EDTA - pH 8, $1 \%$ SDS, $100 \mu \mathrm{g}$ proteinase $\mathrm{K}$ in $1 \mathrm{ml} \mathrm{H}_{2} \mathrm{O}$ ) immediately. Lysates were stored at $4{ }^{\circ} \mathrm{C}$ until DNA electrophoresis (1.8\% agarose). Neutral gel electrophoresis was proceeded (using MiroGene Comp. equipment) in TBE buffer (5.4 g Tris base, $2.75 \mathrm{~g}$ boric acid, 0.5 M EDTA - pH 8 in $\left.1000 \mathrm{ml} \mathrm{H}_{2} \mathrm{O}\right)$. DNA in the gel was stained by ethidiumbromide $(1 \mu \mathrm{g} / \mathrm{ml})$ and photodocumented.

TUNEL AP test

Terminal deoxynucleotidyl transferase-mediated dUTP nick end labeling (Gavrieli et al. 1992) was used for proving apoptosis in individual cells. TUNEL test was proceeded following producer's directions (BoehringerMannheim). After conversion using substrate for alkaline phosphatase (Fast Red, Sigma-Aldrich) cells were counted under light microscope.

\section{Cell morphology}

To evaluate morphological changes characteristic for apoptosis, cells were stained with May-Grünwald-Giemsa and examined by oil immersion under light microscope at a magnification of $\times 1000$.

\section{Results and Discussion}

The aim of this study was to observe interaction between prokaryotic and eukaryotic cell during phagocytic process and its influence on apoptosis activation. DNA Ladder Assay was used for qualitative detection of apoptotic DNA changes, TUNEL AP for quantification of apoptotic cells (red - cells with DNA breaks - Fig. 2). The number of apoptotic cells was statistically tested using Student's $t$-test (Benedík et Dušek 1993).

Blood samples from 12 healthy adult pigs with physiological value of leukocytes (18$21 \mathrm{G} / 1)$ were examined. Using microspheric particles, phagocytic index (5.3-7.5) and 
phagocytic activity (80-95\%) of granulocytes were evaluated. Our observation was focused on granulocytes, with examination of apoptotic morphology in monocytes and lymphocytes. To determine whether apoptosis is induced spontaneously or in consequence of phagocytosis, we used a negative untreated control. To distinguish the influence of phagocytic process itself from factors of killed and living bacteria, respectively, we cultivated one group with microspheric particles. All samples were cultivated up to $48 \mathrm{~h}$, and to avoid bacterial cell division during cultivation, ampicilin $(100 \mathrm{ng} / \mathrm{ml})$ was added. Bactericidal capacity of phagocytes was evaluated after separation of free bacteria, the decrease in number of living bacteria cells inside phagocytes was more than $99 \% / 2 \mathrm{~h}$.

Analyzed by light microscopy, monocytes exhibited altered morphology (disintegration of nuclei) after $4 \mathrm{~h}$ of cultivation in the group with living bacteria, in the control group after $12 \mathrm{~h}$. In contrast, lymphocytes did not show any morphological features of apoptotic cells in the course of this experiment. Because of small percentage of monocytes in total leukocytes, no apoptotic ladder was observed by gel electrophoresis in the group with living bacteria after $4 \mathrm{~h}$ of cultivation. On the other hand, in granulocytes in groups engulfed particles and killed bacterial cells, DNA fragmentation was proved by gel electrophoresis after 4 hours while control group was negative (Fig. 3 ). Significant $(t$-test, $\mathrm{P}<0.01)$ smaller amount of apoptotic cells in the control and group with living bacteria in comparison with other groups was confirmed by TUNEL AP test (Fig. 1) after $4 \mathrm{~h}$ cultivation. In contrast, apoptotic DNA ladder in analysed DNA taken after $48 \mathrm{~h}$, was proved only in the group with living bacteria. The other groups showed features of necrosis (Fig. 4).

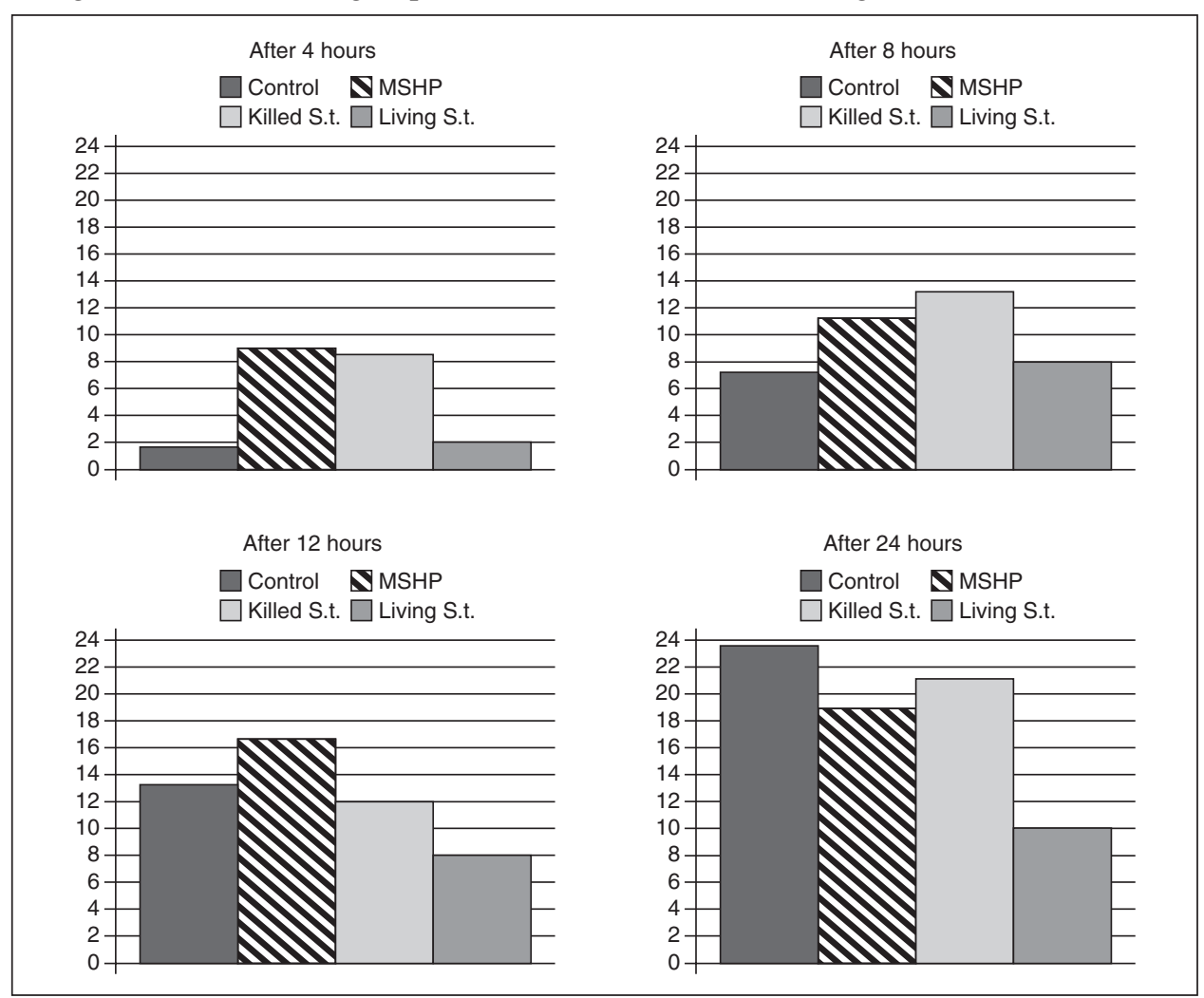

Fig. 1. Percentage of apoptotic cells in total leukocytes using TUNEL AP in given intervals. 
Our results suggest that phagocytosis by itself activates the apoptotic programme in granulocytes of the pig immune system but the presence of phagocyted living $S$. typhimurium LB 5000 can slow down its activation. This prolonged survival of short-lived cells seems to be very important for the elimination of pathogens during non-specific immune response of the organism (B aran et al. 1996).

\section{Apoptotické změny DNA v prasečích leukocytech po fagocytóze bakteriálních buněk Salmonella typhimurium}

Pohlcení a následné usmrcení mikroorganismů jsou dvě důležité úlohy leukocytů při nespecifické imunitní odpovědi organismu.

Tato studie byla zaměřena na interakce prokaryotické a eukaryotické buňky při fagocytóze extracelulárních bakterií prasečími leukocyty, zejména vliv fagocytárního procesu na aktivaci apoptotického programu fagocytujících buněk. Cílem práce bylo sledování, jak může fagocytární proces a následná cidie mikroorganismů ovlivnit přežívání prasečích leukocytů.

Krevní vzorky ze 12 prasat (Duroc, věk 4 měsíce) byly inkubovány se suspenzí bakteriálních buněk Salmonella typhimurium LB 5000 po dobu 48 hodin při $37{ }^{\circ} \mathrm{C}$. Souběžně byla kultivována kontrolní skupina, skupina s mikrosférickými partikulemi a s usmrcenými bakteriálními buňkami. V několika časových intervalech byly odebírány vzorky pro analýzu DNA. Průkaz apoptotického žebříčku po elektroforéze umožnil detekci apoptotických zlomů DNA a TUNEL AP test byl využit ke kvantifikaci apoptotických změn v jednotlivých buňkách. Buněčná morfologie byla sledována na krevních nátěrech barvených May-Grünwald-Giemsa.

Leukocyty ve vzorcích inkubovaných s usmrcenými bakteriemi a mikrosférickými částicemi vykazovaly apoptotické změny DNA po 4 hodinách kultivace. Spontánní apoptotický proces byl detekován v kontrolách po 8 hodinách kultivace. Ve skupině s živými bakteriálními buňkami byl po 48 hodinách pozorován odklad aktivace apoptotického programu, kdy ostatní skupiny vykazovaly známky nekrózy.

Naše výsledky naznačují, že fagocytární proces sám o sobě aktivuje apoptotický program ve fagocytujících buňkách imunitního systému prasečího organismu, ale př́tomnost fagocytovaných živých bakteriálních buněk $S$. typhimurium může tuto aktivaci zpomalit.

Toto prodloužené přežívání jinak krátce žijících buněk se zdá být velmi důležité pro eliminaci patogenů během nespecifické imunitní odpovědi organismu.

\section{Acknowledgements}

This study was supported by the Ministry of Education CR (grant FRVŠ 1239/1999), Veterinary and Pharmaceutical University Brno (grant IGA VFU 05/98) and by project CEZ: J 16/98 161700001 FVL VFU Brno.

\section{References}

ALLEN, R. T., HUNTER, I. W. J., ARGAWAL, D. K. 1997: Morphological and biochemical characterization and analysis of apoptosis. J. Pharmacol. Toxicol. 37: 215-228

BARAN, J., GUZIK K., HRYNIEWICZ, W., ERNST, M., FLAD, H.-D., PRYJMA, J. 1996: Apoptosis of monocytes and prolonged survival of granulocytes as a result of phagocytosis of bacteria. Infection and Immunity 64: 4242-4248

BENEDÍK, J., DUŠEK, L. 1993: Sbírka př́íkladů z biostatistiky. Skripta Konvoj, Brno 151 p.

FESUS, L., DAVIES, P. J. A., PIACENTINI, M. 1991: Apoptosis: molecular mechanisms in programmed cell death. Eur. J. Cell Biol. 56:170-177

GAVRIELI, Y., SHERMAN, Y., BENSASSON, S. A. 1992: Identification of programmed cell death in situ via specific labeling of nuclear DNA fragmentation. J. Cell. Biol. 119: 493-501

HALE, A. J., SMITH, C. A., SUTHERLAND, L. C., STONEMAN, V. E., LONGTHORNE, V., CULHANE, A. C., WILLIAMS, G. T. 1996: Apoptosis: molecular regulation of cell death. Eur. J. Biochem. 237: 884

KERR, J. F. R., WYLLIE, A. H., CURRIE, A. R. 1972: Apoptosis - A basic biological phenomenon with wideranging implications in tissue kinetics. Br. J. Cancer 26: 239-257 
LAWRENCE, G. G. 1992: New pathways of phagocyte activation: the coupling of receptor-linked phospholipase $\mathrm{D}$ and the role of tyrosine kinase in primed neutrophils. FEMS Microbiol. Immunol. 105: 229-238

MESZAROS, A. J., REICHNER, J. S., ALBINA, J. E. 1999: Macrophage phagocytosis of wound neutrophils. J. Leukocyte Biol. 65: 35-42

MOREL, F., DOUSSIERE, J., VIGNAIS, P. V. 1991: The superoxide generating oxidase of phagocytic cells. Physiological, molecular and pathological aspects. Eur. J. Biochem. 201: 523-546

SLÁDEK, Z., RYŠÁNEK, D. 1999: Apoptosis of polymorphonuclear leukocytes. Vet. Med-Czech 44: 309-320

WYLLIE, A. H., KERR, J. F. R., CURRIE, A. R.1980: Cell death: the significance of apoptosis. Int. Rev. Cytol. 68: $251-306$ 
Plate I

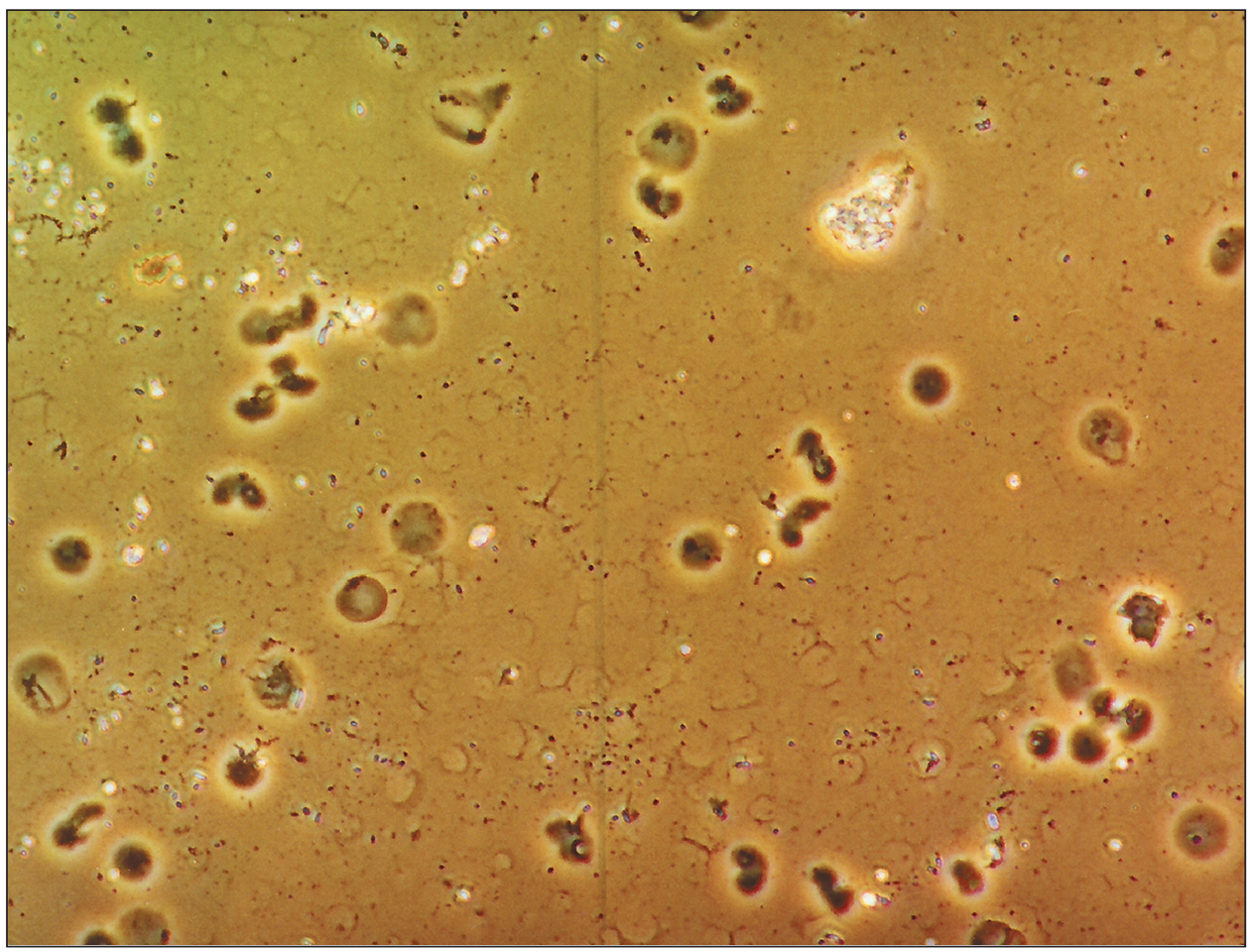

Fig. 2. TUNEL AP test proving apoptotic DNA fragmentation in leukocytes; a) Cell nuclei without fragmentation (see above), b) Cell nuclei with DNA fragmentation (red), (see below).

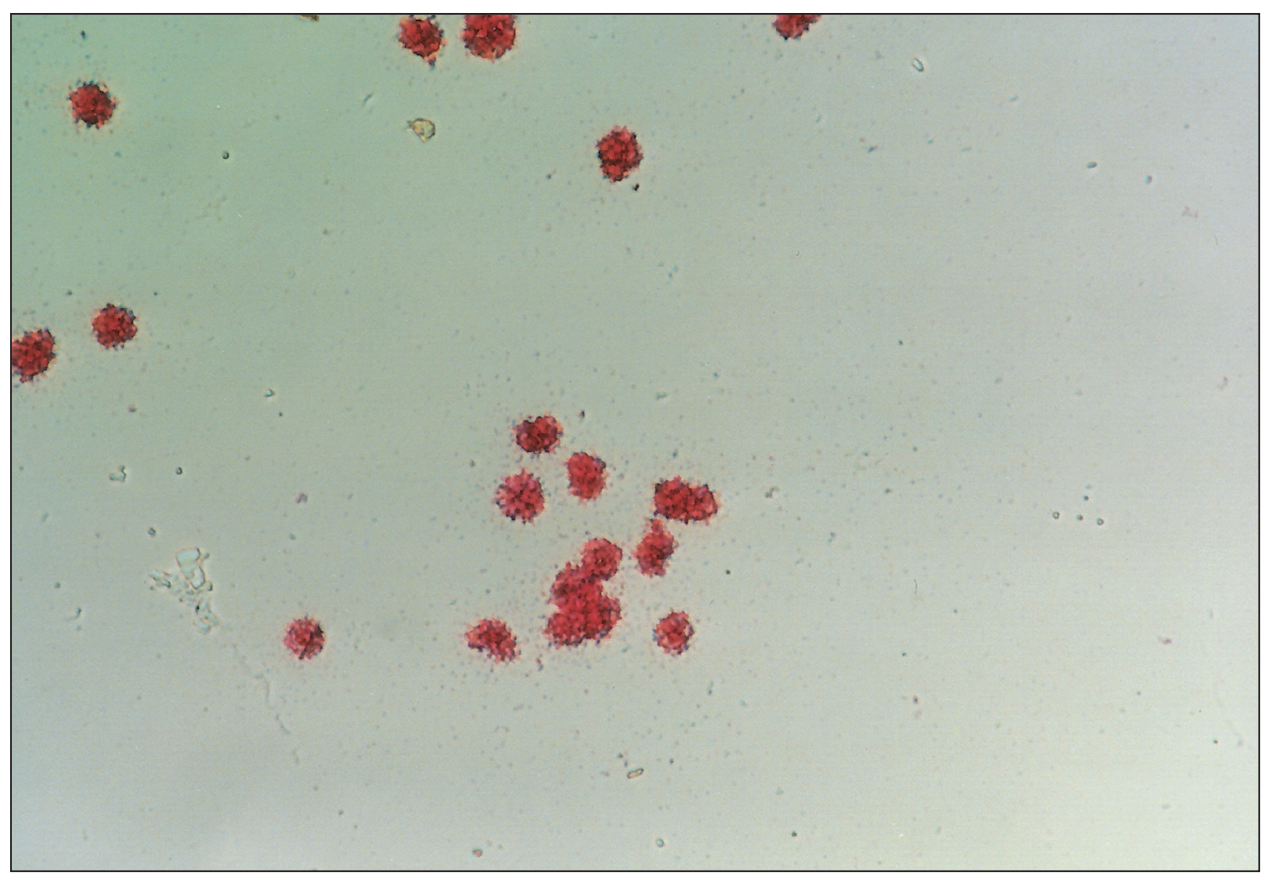


Plate II

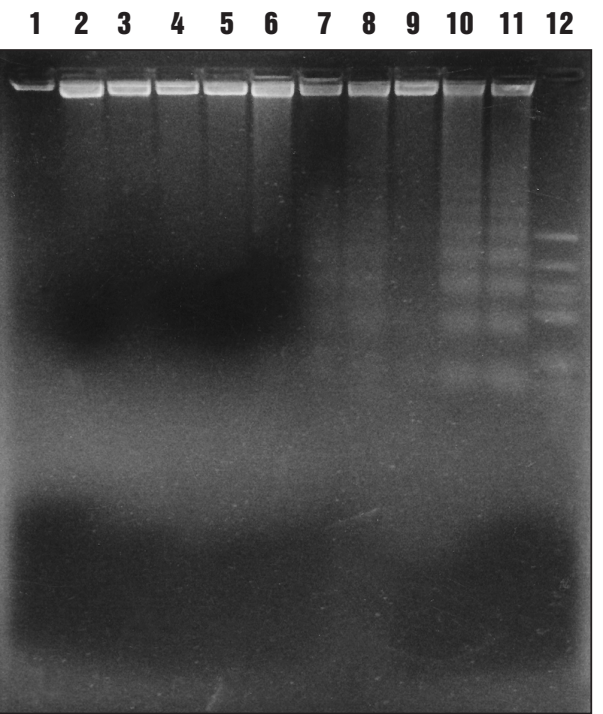

$\begin{array}{llllllllllll}13 & 14 & 15 & 16 & 17 & 18 & 19 & 20 & 21 & 22 & 23 & 24\end{array}$

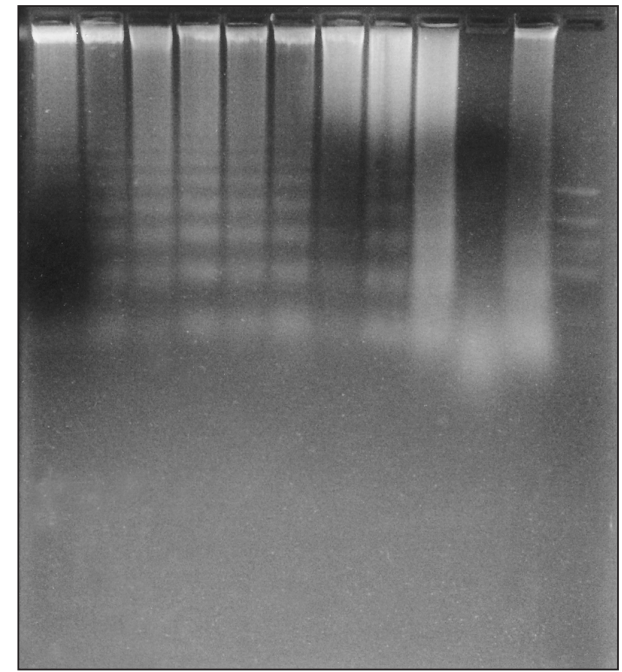

Fig. 3. DNA ladder assay.

Comparison of all groups (A-control, B-group with MSHP, C-group with killed bacteria, D-group with living bacteria Salmonella typhimurium LB 5000) at intervals of $0,1,4,8$ and $12 \mathrm{~h}$ after the beginning of the experiment. Runs: 1- 0 h, 2- A/1h, 3- B/1h, 4- C/1h, 5- D/1h, 6- A/4h, 7- B/4h, 8- C/4h, 9- D/4h, 10- A/8h, 11- B/8h, 12- DNA marker (970-155 bp), 13- C/8h, 14- D/8h, 15- A/12h, 16- B/12h, 17- C/12h, 18- D/12h, 19- A/24h, 20- B/24h, 21- C/24h, 22- D/24h, 23- A/48h, 24- DNA marker (970-155bp).

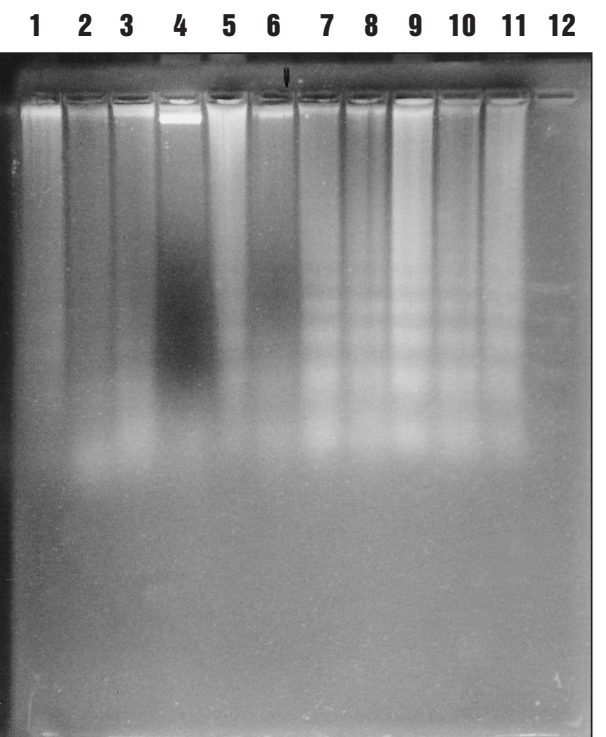

Fig. 4. DNA ladder assay.

Control (runs 1-6) and group with living bacteria (runs 7-11) after $48 \mathrm{~h}$ of cultivation. Run 12- DNA marker (970-155bp). 